Vol 2. No. 1, Januari 2022 P-ISSN : 2774-8030, e-ISSN : 2774-8030

\title{
PENGARUH PENYUSUNAN ANGGARAN DAN EFEKTIVITAS LAPORAN KEUANGAN TERHADAP KINERJA MANAJERIAL DENGAN GAYA KEPEMIMPINAN SEBAGAI VARIABEL MODERASI
}

\author{
IRMA YUNITA \\ Universitas Mathla'ul Anwar Banten \\ e-mail: yunitairma724@gmail.com
}

\begin{abstract}
ABSTRAK
Gaya kepemimpinan sebuah lembaga/organisasi masih dianggap otoriter oleh sebagian masyarakat didaerah. Perlu menumbuhkan jiwa leadership yang tinggi seorang pemimpin sehingga kinerja manajerial karyawan melalui beberapa aspek yang dapat dikaji lebih dalam. Kinerja manajerial Penelitian ini bertujuan untuk menanamkan gaya kepemimpinan yang baik yang dapat di jadikan teladan dalam meningkatkan kinerja manajerial karyawan melalui aspek partisipasi anggaran dan pelaporan laporan keuangan sehingga tujuan utama organisasi dapat tercapai dengan baik. Dengan menggunakan metode penelitian assosiatif melalui pendekatan deskriptif. Populasi yang ada sebanyak 95 karyawan BPKD Kabupaten pandeglang. Dengan sampel 30 responden melalui Tehnik pengambilan simple dengan metode purposive sampling. Hasil yang didapatkan dengan beberapa analisis didapatkan bahwa Secara parsial partisipasi anggaran berpengaruh dan signifikan terhadap kinerja manajerial. Efektifitas laporan keuangan tidak berpengaruh dan tidak signifikan terhadap kinerja manajerial. Sedangkan hasil dari efek mediasi gaya kepemimpinan secara parsial partisipasi anggaran terhadap kinerja manajerial memiliki hubungan yang signifikan berbeda dengan efek moderasi gaya kepemimpinan tidak mampu menjadi moderasi antara efektifitas laporan keuangan terhadap kinerja manajerial.
\end{abstract}

Kata Kunci: Partisipasi anggaran, Efektifitas Laporan Keuangan,Kinerja Manajerial,Gaya kepemimpinan

\begin{abstract}
The leadership style of an institution/organization is still considered authoritarian by some people in the area. It is necessary to cultivate a high leadership spirit as a leader so that the managerial performance of employees through several aspects can be studied more deeply. Managerial performance This study aims to instill a good leadership style that can be used as an example in improving employee managerial performance through aspects of budget participation and financial reporting so that the main goals of the organization can be achieved properly. By using associative research method through descriptive approach. The population is 95 employees of BPKD Pandeglang Regency. With a sample of 30 respondents through a simple sampling technique with purposive sampling method. The results obtained by several analyzes show that partially budgetary participation has a significant and significant effect on managerial performance. The effectiveness of financial statements has no effect and is not significant on managerial performance. While the results of the mediating effect of leadership style partially budgetary participation on managerial performance have a significantly different relationship with the moderating effect of leadership style not being able to moderate the effectiveness of financial statements on managerial performance.
\end{abstract}

Keywords: Budget participation, Effectiveness of Financial Statements, Managerial Performance, Leadership style

\section{PENDAHULUAN}

Kinerja manajerial merupakan kontributor utama dalam kelangsungan hidup sebuah organisasi. Salah satu faktor dalam menentukan kinerja manajerial yaitu partisipasi anggaran(Ermawati, 2017). Anggaran merupakan kegiatan yang terstruktur yang berisi aktifitas-aktifitas perencanaan secara berkesinambungan untuk periode yang akan datang untuk mewujudkan tujuan organisasi. Tujuan anggaran adalah sebagai pedoman dalam mengukur 
efisiensi biaya dan mengidentifikasi masalah dan mengontrol biaya. Dengan Anggaran pimpinan dapat melakukan koordinasi, komunikasi dan penilaian kinerja terhadap bawahannya. Dalam penyusunan anggaran perlu melibatkan manajememn pada level yang lebih rendah hal ini dibutuhkan untuk mencegah efek fungsional atau disfungsionalnya dalam perilaku berorganisasi(Ermawati, 2017).

Penyusunan Sebuah anggaran baik di sector swasta maupun disektor pemerintahan sudah umum dilakukan untuk mengontrol dan mengetahui pertumbuhan industri dan pertumbuhan wilayah. Dalam penyusunan laporan keuangan pemerintah diatur oleh Peraturan Pemerintah No. 58 Tahun 2005 tentang pengelolaan keuangan daerah. Dalam sebuah wilayah otorisasai penyusunan anggaran dilakukan oleh pemerintah setempat dengan berpedoman pada Peraturan Menteri dalam negeri Republik Indonesia no. 109 Tahun 2016 tentang pedoman penyusunan anggaran pendapatan dan belanja daerah tahun anggaran (Handayati \& Safitri, 2020). Pada Anggaran Pendapatan Daerah (APBD) Pemkab Pandeglang pada Tahun anggaran 2018 mengalami defisit APBD yang diakibatkan oleh kepala BPKD Kabupaten Pandeglang karena terlalu optimis dalam mengasumsikan sisa lebih perhitungan anggaran (SILPA) di tahun 2017. Namun akibat perhitungan yang terlalu melampui, yang seharusnya SILPA hanya Rp.200.000.000.000,00 malah tercatat Rp.275.000.000.000,00 sehingga ada defisit pada APBD TA 2018 ini yang jumlahnya hingga mencapai Rp.75.000.000.000,00 (fajarbanten.com 2018).Hal ini menyatakan bahwa masih lemahnya efektifitas pelaporan keuangan sehingga menimbulkan asumsi masyarakat terhadap kinerja manajerial pemerintahan masih kurang optimal. Efektifitas sebuah laporan keuangan memiliki banyak faktor penting yang harus dimiliki pemerintahan untuk proses penyusunan laporan keuangan.

Kinerja aparatur atau staf manajemen merupakan gambaran dari pencapaian pelaksanaan kegiatan organisasi sector publik. Kinerja manajerial sangat penting untuk berkelangsungan hidup organisasi. Terutama organisasi sektor publik dimana kinerja manajerial merupakan hasil kerja organisasi dalam melaksanakan kegiatan pada masyarakat (Annisa et al., 2020). Namum untuk dapat meningkatkan kinerja pemerintah daerah diperlukan sistem pengelolaan keuangan daerah yang terstruktur dimulai dari proses perencanaan, penganggaran APBD, pelaksanaan/penatausahaan APBD serta pertanggungjawaban pelaksanaan APBD dengan pengawasan dan pengendalian internal yang terarah(Annisa et al., 2020). Namun beberapa literatur empiris belum meneliti tentang gaya consideration dalam memimpin pemerintahan. Consideration merupakan gaya kepemimpinan yang memiliki dampak positif yang kuat dalam mendorong penyusunan anggaran.

Beberapa penelitian terdahulu (Iswahyudi et al, 2020) dan (Annisa et al., 2020) menyimpulkan bahwa penyusunan anggaran berpengaruh terhadap kinerja manajerial. Semakin baik penyusunan anggaran dilakukan maka semakin baik pula penilaian terhadap kinerja manajerialnya. Namun hal ini tidak didukung oleh penelitian (Yuniarti \& Saty, n.d.) dan (Medhayanti \& Suardana, 2015) yang mengemukakan bahwa penyusunan anggaran berpengaruh negatif terhadap kinerja manajerial. Dapatkah gaya kepemimpinan ini diterapkan pada sector pemerintah sehingga penyusunan anggaran dan efektifitas pelaporan keuangan mampu berkontribusi terhadap kinerja manajerial. Tujuan penelitian ini untuk mengembangkan dan menguji kinerja manajerial dengan mengunakan gaya consideration dalam memimpin pada sector publik. Tujuan pertama penelitian untuk mengetahui pengaruh partisipasi penyusunan anggaran dan efektifitas laporan keuangan berpengaruh terhadap kinerja manajerial secara parsial dan simultan Tujuan kedua untuk mengetahui gaya consideration dalam memoderasi partisipasi penyusunan anggaran terhadap kinerja manajerial,ketiga menguji pengaruh mediasi efektifitas pelaporan keuangan terhadap keputusan manajerial.

\section{METODE PENELITIAN}

Metode yang digunakan dalam penulisan penelitian ini yaitu Penelitian assosiatif dengan pendekatan deskriptif kuantitatif, yaitu data yang dikumpulkan dan dianalisis dengan 
menggunakan uji analisis statistik. Penelitian deskriptif meliputi penilaian sikap atau pendapat individu, organisasi, keadaan, ataupun prosedur (Sugiyono, 2019).

Populasi pada penelitian ini yaitu seluruh karyawan atau pegawai perusahaan yang bekerja di Badan Pengelola Keuangan Daerah di kabupaten Pandeglang yang berjumlah 95 oarang dimana ada beberapa bagian diantaranya bagian Kesekretariatan 19 orang, Bidang Perbendaharaan dan Kas Daerah 16 orang, Bidang Akuntansi 15 orang, Bidang Anggaran 15 orang dan Bidang Barang Milik Daerah 20 orang jadi seluruhnya berjumlah 95 pegawai. Teknik pengambilan sampel dalam penelitian ini adalah teknik pengambilan sampel purposive sampling. Purposive sampling adalah teknik pengambilan sampel dengan menggunakan kriteria-kriteria tertentu (Sugiyono, 2019). Kriteria yang digunakan adalah berdasarkan pertimbangan (judgment), sehingga disebut judgment sampling. Kriteria yang digunakan dalam penelitian ini adalah pegawai/staf yang bertanggung jawab dalam Bidang Akuntansi dan dan Bidang Anggaran di Badan Pengelolaan Keuangan Daerah ( BPKD ) Kabupaten Pandeglang sebanyak 30 responden.

Penelitian ini menggunakan metode pengumpulan data dengan menggunakan kuesioner yang diberikan kepada responden terpilih melalui metode yang sudah ditetapkan. Pengukuran dilakukan dengan skala Likert 1 sampai 5 untuk mengukur untuk mengukur sikap, pendapat, dan persepsi seseorang atau sekelompok orang tentang fenomena sosial (Sugiyono, 2019). Variabel penelitian ini adalah variabel independen dan variabel dependen serta variabel moderasi. Variabel moderasi (moderating) merupakan variabel yang memiliki pengaruh terhadap sifat atau arah hubungan antar variabel (Sugiyono, 2019). Variabel independen partisipasi anggaran dan efektifitas laporan keuangan yang dilambangkan dengan X1 dan X2 . Variabel dependen adalah kinerja manajerial yang dilambangkan Y, sedangkan variabel moderasi gaya Consideration dilambangkan Z. Penelitian ini menggunakan analisis Moderated Regression Analysis (MRA) untuk mengukur efek moderasi terhadap variabel X1,X2 dan Y. Dengan menggunakan rumus Persamaan moderasi sebagai berikut: $Y=a+b 1 X 1+b 2 X 2$ $+b 3(X 1-Z)+b 3(X 2-Z)+e$; dimana: $\mathrm{Y}=$ variabel dependen (Kinerja Kinerja) $\mathrm{X} 1=$ variabel independen pertama (partisipasi anggaran), X2 = variabel independen kedua (Efektifitas laporan keuangan), $\mathrm{Z}=$ variabel moderasi (gaya consideartion).

\section{HASIL DAN PEMBAHASAN}

Hasil

Pada penelitian ini, penulis melakukan penelitian pada pegawai di Badan Pengelola Keuangan Daerah Kabupaten Pandeglang Tahun 2021 dengan deskripsi profil responden yang meliputi jenis kelamin, usia, lama bekerja, dan pendidikan. Dalam kegiatan penelitian ini yang menjadi responden berjumlah 30 orang yang memiliki identitas yang beragam sebagaimana disajikan dalam table di bawah ini:

Tabel 1 Profil Responden

\begin{tabular}{|c|c|c|c|}
\hline No & Profil Responden & Jumlah & Persentase \\
\hline \multirow[t]{4}{*}{1} & Jenis kelamin: & & \\
\hline & Laki-Laki & 13 & $43 \%$ \\
\hline & Perempuan & 17 & $57 \%$ \\
\hline & Total & 30 & $100 \%$ \\
\hline \multirow[t]{6}{*}{2} & Usia: 21 - 30 & & \\
\hline & $31-40$ & 7 & $23 \%$ \\
\hline & $41-50$ & 15 & $50 \%$ \\
\hline & $>50$ & 6 & $20 \%$ \\
\hline & & 2 & $7 \%$ \\
\hline & Total & 30 & $100 \%$ \\
\hline
\end{tabular}


3 Latar Belakang Pendidikan

$\begin{array}{lcc}<\text { D3 D3 } & 5 & 16 \% \\ \text { SI } & 6 & 20 \% \\ \text { S2 } & 17 & 57 \% \\ & 2 & 7 \% \\ \text { Total } & 30 & 100 \% \\ \text { Lama Bekerja: } 1-5 & & \\ 6 & 5 & 16 \% \\ -10 & 9 & 30 \% \\ >10 & 16 & 54 \% \\ \text { Total } & & \mathbf{1 0 0 \%}\end{array}$

Berdasarkan tabel di atas dapat disimpulkan bahwa pada kantor BPKD Kabupaten Pandeglang di dominasi oleh perempuan dengan latar belakang pendidikan S1 dan lama bekerja sudah rata2 di atas 10 tahun. Hal ini menunjukan kualitas sumber daya manusia di lingkungan kerja BPKD Kabupaten Pandeglang memenuhi kualifikasi yang baik.

\section{Uji Deskriptif}

Dari data kuesioner terkumpul yang telah disebarkan dan kemudian ditabulasi dengan tujuan sebagai alat analisis data, hasil dari tabulasi tersebut diolah menggunakan SPSS versi 26. Statistic deskriptif ini memberikan gambaran mengenai variabel-variabel penelitian dalam penelitian ini partisipasi anggaran, efektivitas laporan keuangan dan kinerja manajerial dan gaya kepemimpinan maka digunakan table statistic deskriptif yang menunjukan angka nilai minimum, maksimum, rata-rata (mean) dan standar deviasi yang dapat dilihat dalam table 5.2 dibawah ini:

\section{Tabel 2. Uji Deskriptif} Descriptive Statistics

\begin{tabular}{|c|c|c|c|c|c|c|}
\hline & \multirow{2}{*}{$\begin{array}{c}\mathrm{N} \\
\text { Statistic }\end{array}$} & \multirow{2}{*}{$\begin{array}{c}\text { Minimum } \\
\text { Statistic }\end{array}$} & \multirow{2}{*}{$\begin{array}{c}\text { Maximum } \\
\text { Statistic }\end{array}$} & \multicolumn{2}{|r|}{ Mean } & \multirow{2}{*}{$\begin{array}{c}\text { Std. } \\
\text { Deviation } \\
\text { Statistic }\end{array}$} \\
\hline & & & & $\begin{array}{l}\text { Statist } \\
\text { ic }\end{array}$ & $\begin{array}{l}\text { Std. } \\
\text { Error }\end{array}$ & \\
\hline Partisipasi Anggaran & 30 & 40 & 49 & 44.03 & .422 & 2.312 \\
\hline Kinerja Manajerial & 30 & 37 & 59 & 48.33 & .861 & 4.715 \\
\hline $\begin{array}{l}\text { Efektivitas Laporan } \\
\text { Keuangan }\end{array}$ & 30 & 38 & 50 & 45.00 & .555 & 3.040 \\
\hline Gaya Kepemimpan & 30 & 39 & 48 & 43.93 & .439 & 2.406 \\
\hline Valid N (listwise) & 30 & & & & & \\
\hline
\end{tabular}

(Sumber : Data diolah peneliti 2022)

\section{Uji Instrumen Penelitian}

\section{a. Uji Validitas}

Pengujian validitas data dilakukan dengan menggunakan software statistic yaitu korelasi antara masing-masing pernyataan dengan skor total dengan menggunakan metode product moment pearson correlation. Jika $\mathrm{r}$ hitung yang merupakan nilai dari Corrected Item-Total 
Correlation> dari $\mathrm{r}$ table pada signifikan 0,05 (5\%) maka data dinyatakan valid. Dalam penelitian ini jumlah data (n) sebanyak 30 sehingga $r$ table pada signifikan 0,05 adalah 0,361. Pengujian validitas data dilakukan dengan menggunakan pendekatan pearson correlation.

Tabel 3. Hasil Uji Validitas

\begin{tabular}{|c|c|c|c|c|}
\hline Variabel & Item No & r Hitung & r Tabel & Hasil \\
\hline \multirow{7}{*}{ Partisipasi Anggaran } & $\mathrm{P}-1$ & 0,396 & 0,361 & Valid \\
\hline & $\mathrm{P}-2$ & 0,601 & 0,361 & Valid \\
\hline & $\mathrm{P}-3$ & 0,534 & 0,361 & Valid \\
\hline & $\mathrm{P}-4$ & 0,427 & 0,361 & Valid \\
\hline & P-5 & 0,377 & 0,361 & Valid \\
\hline & P-6 & 0,497 & 0,361 & Valid \\
\hline & P-7 & 0,537 & 0,361 & Valid \\
\hline \multirow{15}{*}{$\begin{array}{l}\text { Efektivitas } \\
\text { Keuangan }\end{array}$} & P-8 & 0,415 & 0,361 & Valid \\
\hline & P-9 & 0,555 & 0,361 & Valid \\
\hline & $\mathrm{P}-10$ & 0,368 & 0,361 & Valid \\
\hline & $\mathrm{P}-1$ & 0,682 & 0,361 & Valid \\
\hline & $\mathrm{P}-2$ & 0,787 & 0,361 & Valid \\
\hline & $\mathrm{P}-3$ & 0,565 & 0,361 & Valid \\
\hline & $\mathrm{P}-4$ & 0,385 & 0,361 & Valid \\
\hline & $\mathrm{P}-5$ & 0,597 & 0,361 & Valid \\
\hline & P-6 & 0.498 & 0,361 & Valid \\
\hline & P-7 & 0,514 & 0,361 & Valid \\
\hline & $\mathrm{P}-8$ & 0,839 & 0,361 & Valid \\
\hline & P-9 & 0,600 & 0,361 & Valid \\
\hline & $\mathrm{P}-10$ & 0,413 & 0,361 & Valid \\
\hline & $\mathrm{P}-11$ & 0,648 & 0,361 & Valid \\
\hline & $\mathrm{P}-12$ & 0,648 & 0,361 & Valid \\
\hline \multirow{9}{*}{ Kinerja Manajerial } & $\mathrm{P}-1$ & 0,535 & 0,361 & Valid \\
\hline & $\mathrm{P}-2$ & 0,686 & 0,361 & Valid \\
\hline & $\mathrm{P}-3$ & 0,775 & 0,361 & Valid \\
\hline & $\mathrm{P}-4$ & 0,616 & 0,361 & Valid \\
\hline & $\mathrm{P}-5$ & 0,425 & 0,361 & Valid \\
\hline & P-6 & 0,596 & 0,361 & Valid \\
\hline & P-7 & 0,671 & 0,361 & Valid \\
\hline & $\mathrm{P}-8$ & 0,591 & 0,361 & Valid \\
\hline & P-9 & 0,518 & 0,361 & Valid \\
\hline \multirow{11}{*}{ Gaya Kepemimpinan } & $\mathrm{P}-10$ & 0,450 & 0,361 & Valid \\
\hline & $\mathrm{P}-1$ & 0,369 & 0,361 & Valid \\
\hline & $\mathrm{P}-2$ & 0,629 & 0,361 & Valid \\
\hline & $\mathrm{P}-3$ & 0,535 & 0,361 & Valid \\
\hline & $\mathrm{P}-4$ & 0,768 & 0,361 & Valid \\
\hline & $\mathrm{P}-5$ & 0,449 & 0,361 & Valid \\
\hline & P-6 & 0,445 & 0,361 & Valid \\
\hline & P-7 & 0,449 & 0,361 & Valid \\
\hline & P-8 & 0,483 & 0,361 & Valid \\
\hline & P-9 & 0,460 & 0,361 & Valid \\
\hline & P-10 & 0,402 & 0,361 & Valid \\
\hline
\end{tabular}

(Sumber : Data diolah peneliti 2022)

Hasil pengujian validitas diatas menunjukan bahwa semua item di dalam variabel partisipasi anggaran, efektivitas laporan keuangan dan kinerja manajerial dengan Gaya 
Kepemimpinan yang di uji dalam penelitian dinyatakan bahwa masing-masing instrument pernyataan dianggap valid karena nilai Corrected Item-Total Correlation> dari $\mathrm{r}$ pada signifikan 0,05 (5\%).

\section{b. Uji Reliabilitas}

Uji reliabilitas digunakan untuk mengetahui konsistensi aalat ukur, apakah alat ukur yang digunakan dapat diandalkan dan tetap konsisten jika pengukuran tersebut diulang. Uji reliabilitas data yang digunakan dalam penelitian ini adalah metode Cronbach's Alpha. Suatu kuesioner dikatak reliable jika jawaban dari responden itu lebih stabil dari waktu ke waktu. Kriteria suatu instrument penelitian dikatakan reliable jika menggunakan uji statistic Cronbach Alpha (a), koefesien reliabilitas >0,60. Hasil uji reliabilitas dapat dilihat dari table berikut:

Tabel 4. Hasil Uji Reliabilitas

\begin{tabular}{lccc}
\hline \multicolumn{1}{c}{ Variabel } & $\begin{array}{c}\text { Cronbach's } \\
\text { Alpha }\end{array}$ & $\begin{array}{c}\text { Batas } \\
\text { Reliabilitas }\end{array}$ & Hasil \\
Partisipasi Anggaran (X1) & 0,606 & 0,60 & Reliabel \\
$\begin{array}{l}\text { Efektivitas Laporan Keuangan } \\
\text { (X2) }\end{array}$ & 0,796 & 0,60 & Reliabel \\
Kinerja Manajerial (Y) & 0,787 & 0,60 & Reliabel \\
Gaya Kepemimpinan (M) & 0,666 & 0,60 & Reliabel \\
\hline
\end{tabular}

(Sumber : Data diolah peneliti 2022)

Tabel 5.8 diatas menunjukan bahwa nilai Cronbach's Alpha dari semua variabel lebih besar dari 0,60 sehingga dapat disimpulkan bahwa instrument dari kuesioner yang dugunakan untuk menjelaskan variabel partisipasi anggaran, kinerja manajerial, efektivitas laporan keuangan dan komitmen organisasi yaitu dinyatakan handal atau dapat dipercaya sebagai alat ukur variabel.

\section{Uji Korelasi Pearson}

Teknik korelasi yang digunakan adalah korelasi product moment pearson, yaitu untuk mengetahui derajat atau arah kekuatan hubungan timbal balik antar variabel. Hubungan antar variabel terdiri dari hubungan positif dan negative.

Tabel 5. Uji Korelasi Correlations

\begin{tabular}{|c|c|c|c|c|c|}
\hline \multirow{4}{*}{$\begin{array}{l}\text { Partisipasi } \\
\text { Anggaran }\end{array}$} & \multirow{4}{*}{$\begin{array}{l}\text { Pearson } \\
\text { Correlation }\end{array}$} & \multirow{4}{*}{$\begin{array}{c}\text { Partisipasi } \\
\text { Anggaran } \\
1\end{array}$} & \multicolumn{2}{|c|}{ Efektivitas Kinerja } & \multirow{3}{*}{$\begin{array}{l}\text { Gaya } \\
\text { Kepemim } \\
\text { pinan } \\
\quad .379^{*}\end{array}$} \\
\hline & & & $\begin{array}{l}\text { Laporan } \\
\text { Keuangan }\end{array}$ & Manajerial & \\
\hline & & & & & \\
\hline & & & .059 & .245 & \\
\hline & Sig. (2-tailed) & & .757 & .191 & .039 \\
\hline & $\mathrm{N}$ & 30 & 30 & 30 & 30 \\
\hline Kinerja & Pearson & & & $.577^{* *}$ & \\
\hline Manajerial & Correlation & .059 & 1 & & -.338 \\
\hline & Sig. (2-tailed) & .757 & & .001 & .067 \\
\hline & $\mathrm{N}$ & 30 & 30 & 30 & 30 \\
\hline Efektivitas & Pearson & & $.577^{* *}$ & & \\
\hline Laporan & Correlation & .245 & & 1 & .113 \\
\hline
\end{tabular}


Vol 2. No. 1, Januari 2022 P-ISSN : 2774-8030, e-ISSN : 2774-8030

\begin{tabular}{llcccc}
\hline Keuangan & Sig. (2-tailed) & .191 & .001 & & .552 \\
& $\mathrm{~N}$ & 30 & 30 & 30 & 30 \\
Komitmen & Pearson & $.379^{*}$ & & & \\
Organisasi & Correlation & & -.338 & .113 & 1 \\
& Sig. (2-tailed) & .039 & .067 & .552 & \\
& $\mathrm{~N}$ & 30 & 30 & 30 & 30 \\
\hline
\end{tabular}

(Sumber : Data diolah peneliti dengan SPSS versi 26)

\section{Uji Hipotesis}

Teknik analisis yang digunakan untuk menguji hipotesis meliputi uji koefeisien determinasi dan uji t. Pengujian tersebut dilakukan untuk mengetahui ada tidanya pengaruh variabel independen (partisipasi anggaran dan kinerja manajerial) terhadap variabel dependen (efektivitas laporan keuangan).

Pengujian hipotesis ini untuk menjawab rumusan masalah pertama, kedua, ketiga dan keempat yaitu mengetahui pengaruh partisipasi anggaran, kinerja manajerial yang dimoderasi oleh komitmen organisasi terhadap efektivitas laporan keuangan. Berikut adalah hasil perhitungan dengan menggunakan Moderated Regression Analysis (MRA) dengan menggunakan software SPSS 26.

Tabel 6. Analisis Moderated Regression Analysis (MRA) Coefficients $^{\mathrm{a}}$

\begin{tabular}{|c|c|c|c|c|c|c|}
\hline & Model & $\begin{array}{r}\text { Unstan } \\
\text { Coef }\end{array}$ & $\begin{array}{l}\text { dardized } \\
\text { icients }\end{array}$ & $\begin{array}{l}\text { Standardized } \\
\text { Coefficients }\end{array}$ & $\mathrm{T}$ & Sig. \\
\hline & & B & Std. Error & Beta & & \\
\hline & (Constant) & 406.036 & 168.008 & & 2.417 & .024 \\
\hline & Partisipasi Anggaran & 8.351 & 3.298 & 6.350 & 2.532 & .018 \\
\hline 1 & $\begin{array}{l}\text { Efektifitas Laporan } \\
\text { Keuangan }\end{array}$ & -.256 & 1.873 & -.397 & -.137 & .892 \\
\hline & $\begin{array}{l}\text { Partisipasi Anggaran } \\
*\end{array}$ & .197 & .077 & 11.054 & 2.578 & .017 \\
\hline & $\begin{array}{l}\text { Gaya Kepemimpinan } \\
\text { Efektifitas Laporan } \\
\text { Keuangan * } \\
\text { Gaya Kepemimpinan }\end{array}$ & .016 & .042 & 1.091 & .390 & .700 \\
\hline
\end{tabular}

(Sumber : Data diolah peneliti 2022)

Berdasarkan table 5.10 di atas, dapat disusun persamaan regresi linier berganda sebagai berikut :

$$
Y=406,036+8,351 X^{1}-0,256 X^{2}+0.197 X^{1} M+0,016 X^{2} M+e
$$

Dari persamaan regresi tersebut dapat di simpulkan sebagai berikut:

a. Nilai konstanta sebesar $(406,036)$ artinya bahwa jika variabel partisipasi anggaran * dan efektifitas Laporan keuangan * gaya kepemimpinan sama dengan 0 (nol) maka Kinerja manajerial akan terjadi sebesar (406,036). Artinya bahwa partisipasi anggaran dimoderasi oleh gaya kepemimpinan dengan baik maka kinerja manajerial akan didukung secara signifikan karena adanya variabel gaya kepemimpinan akan meningkatkan kinerja pegawai sehingga akan menghasilkan laporan keuangan yang baik.

b. Koefesien regresi variabel partisipasi anggaran (X1) sebesar 8,351 artinya bahwa jika variabel partisipasi anggaran meningkat $1 \%$ maka akan menaikan kinerja manajerial sebesar 8,351.

c. Koefesien regresi variabel efektifitas laporan keuangan (X2) sebesar $(-0,256)$ artinya 
bahwa jika variabel efektifitas laporan keuangan menurun $1 \%$ maka akan menurunkan kinerja manajemen sebesar $(-0,256)$.

d. Koefesien regresi variabel partisipasi anggaran dengan variabel moderating gaya kepemimpinan sebesar 0,197 artinya bahwa jika meningkat $1 \%$ maka akan meningkatkan kinerja manajerial sebesar 0,197.

e. Koefesien regresi variabel efektifitas laporan keuangan dengan variabel moderating gaya kepemimpinan sebesar 0.016 artinya bahwa jika meningkat $1 \%$ makan akan meningkatkan kinerja manajemen sebesar 0,016.

Tabel 7. Hasil Uji R² Moderated Regression Analysis (MRA)

Model Summary

\begin{tabular}{|c|c|c|c|c|}
\hline Model & R & R Square & $\begin{array}{c}\text { Adjusted R } \\
\text { Square }\end{array}$ & $\begin{array}{c}\text { Std. Error of } \\
\text { the Estimate }\end{array}$ \\
\hline 1 & $.755^{\mathrm{a}}$ & .570 & .480 & 2.192 \\
\hline
\end{tabular}

(Sumber : Data diolah peneliti 2021)

Berdasarkan table 5.11 diatas, diketahui koefesien determinasi $\left(\mathrm{R}^{2}\right)$ sebesar 0,570 atau $57 \%$. Sehingga dapat disimpulkan bahwa partisipasi anggaran, dan efektifitas laporan keuangan yang dimoderasi oleh gaya kepemimpinan terhadap kinerja manajemen mempunyai pengaruh 57\% sedangkan sisanya 43\% dipengaruhi oleh variabel lain diluar model.

Pengujian terakhir untuk H4 ini adalah uji-t atau uji signifikan yang digunakan untuk menguji pengaruh partisipasi anggaran dan efektifitas laporan keuangan yang dimoderasi oleh gaya kepemimpinan terhadap kinerja manajemen. Jika t-test $>\mathrm{t}$ tabel berarti secara individu variabel independen berpengaruh terhadap variabel dependen dan jika besarnya nilai sig lebih kecil dari 0,05 atau 5\% maka secara individu variabel independen berpengaruh signifikan terhadap variabel dependen. Cara mencari t table adalah $\alpha=0,05, \mathrm{t}$ table $\alpha=\mathrm{a} / 2, \mathrm{n}-\mathrm{k}$ yaitu $0,05 / 2=0,025,30-5=25$,

diketahui t-tabel $=$ 2,060. Berdasarkan table 5.10 dapat dilihat perbandingan anatara nilai $t$ table dengan nilai $t$ test seabagai berikut :

Tabel 8. Perbandingan nilai t table dengan nilai t test

\begin{tabular}{lcccc}
\hline \multicolumn{1}{c}{ Variabel } & $\begin{array}{c}\text { Nilai t } \\
\text { test }\end{array}$ & $\begin{array}{c}\text { Nilai t } \\
\text { table }\end{array}$ & $\begin{array}{c}\text { Nilai } \\
\text { Sig }\end{array}$ & Keterangan \\
\hline Partisipasi Anggaran & 2,532 & 2,060 & 0,018 & Diterima \\
$\begin{array}{l}\text { Efektifitas Laporan } \\
\text { Keuangan }\end{array}$ & -0.137 & & 0,892 & Ditolak \\
$\begin{array}{l}\text { Partisipasi Anggaran } \\
*\end{array}$ & 2,578 & & & \\
$\begin{array}{l}\text { Gaya kepemimpinan } \\
\text { Efektifitas Laporan }\end{array}$ & & 2,060 & 0,017 & Diterima \\
$\begin{array}{l}\text { Keuangan * } \\
\text { Gaya kepemimpinan }\end{array}$ & 1,091 & & 0,700 & Ditolak \\
\hline
\end{tabular}

(Sumber : Data diolah peneliti 2022)

\section{Pembahasan}

\section{a. Pengaruh Partisipasi Anggaran Terhadap Efektivitas Laporan Keuangan}

Berdasarkan hasil uji t pata table 5.12 diketahui bahwa partisipasi anggaran memiliki $\mathrm{t}$ hitung sebesar 2,532, $t$ table sebesar 2,060. Dalam hal ini nilai t hitung > t table $(2,532>2,060)$ dengan sig 0,018 hasil tersebut dapat disimpulkan bahwa variabel partisipasi anggaran 
berpengaruh dan signifikan terhadap kinerja manajerial.

Partisipasi penyusunan anggaran memungkinkan para pimpinan tingkat bawah untuk turut serta dalam pembuatan anggaran. Anggaran merupakan alat perencanaan manajerial dalam bentuk keuangan. Anggaran berisi aktifitas-aktifitas yang akan dilakukan secara periode waktu tertentu sebagai acuan kegiatan organisasi dan menunjukkan tujuan operasi. Anggaran juga merupakan alat manajemen untuk melakukan pengendalian, koodinasi, komunikasi, penilaian kinerja dan motivasi. (Ermawati, 2017).

Penelitian sebelumnya yang dilakukan (Ermawati, 2017) mengungkapkan partisipasi anggaran tidak berpengaruh terhadap kinerja manajerial. Adapun penelitian yang lainnya (Wibawa, Suhardiyah, 2021) mengatakan partisipasi penyusunan anggaran berpengaruh positif dan signifikan dengan kinerja manajerial. (Sari et al., 2018) mengungkapkan partisipasi pemakai tidak berpengaruh terhadap efektivitas sistem informasi akuntansi.

\section{b. Pengaruh Efektifitas Laporan Keuangan Terhadap Kinerja manajerial.}

Berdasarkan hasil uji t pada table 5.12 diketahui bahwa Efektifitas laporan keuangaan memiliki t hitung sebesar -0,137, $\mathrm{t}$ table sebesar 2,060. Dalam hal ini nilai t hitung $>\mathrm{t}$ table ($0,137>2,060$ ) dengan sig 0,892 hasil tersebut dapat disimpulkan bahwa variabel efektifitas laporan keuangan tidak berpengaruh dan tidak signifikan terhadap kinerja manajerial.

Efektifitas laporan keuangan merupakan salah satu faktor yang dapat meningkatkan kinerja manajerial, situasi dan kondisi lingkungan yang berubah-ubah (dinamis) menurut pihak manajemen untuk selalu mengikuti perubahan, apabila tidak maka keputusan yang di ambil serta tindakan Organisasi tidak akan sesuai dengan tujuan Organisasi (Ermawati, 2017).

Penelitian sebelumnya yang dilakukan (Saraswati, 2015) analisis yang dihasilkan yaitu efektifitas dan tingkat kesulitan penyusunan sebuah anggaran berpengaruh positif terhadap kinerja manajerial. (Ariska, 2019) mengungkapkan efektivitas sistem informasi akuntansi berpengaruh signifikan terhadap kinerja manajerial. (Dewi et al., 2021) mengatakan kejelasan sasaran anggaran, pengendalian akuntansi dan sistem pelaporan memiliki pengaruh postif terhadap kinerja manajerial.

\section{c. Gaya Kepemimpinan Memoderasi Hubungan Antara Partisipasi Anggaran Terhadap Kinerja Manajerial.}

Berdasarkan hasil uji t pada table 5.10 diketahui bahwa partisipasi anggaran memiliki $\mathrm{t}$ hitung sebesar 2,578, $t$ tabel sebesar 2,060. Dalam hal ini nilai t hitung $>t$ table $(2,578>2,060)$ maka dapat dikatakan signifikan atau dengan kata lain hipótesis diterima artinya ada pengaruh yang signifikan antara variabel independen dengan sig 0,017 artinya dapat disimpulkan bahwa secara bersama-sama variabel independen dengan variabel moderating gaya kepemimpinan mempengaruhi variabel dependen Kinerja manajerial.

Beberapa penelitian di bidang akuntansi mengemukakan bahwa para manajer tingkat bawah mempunyai informasi yang lebih akurat dari pada atasannya mengenai kondisi-kondisi local pusat pertanggungjawaban yang dipimpinnya. Gaya kepemimpinan yang tepat dan banyak dijadikan panutan adalah gaya yang mengarahkan pada keterbukaan dengan lebih bersifat humanis atau gaya ini biasa dikenal dengan gaya Considerabel oleh Coster dan Fertakis dalam (Yuniarti \& Saty, 2017). Adapun penelitian yang lainya (Gunawan \& Santioso, 2015) mengungkapkan partisipasi anggaran berpengaruh positif pada kinerja manajerial dengan variable mediasi yang berbeda yaitu komitmen organisasi.

\section{d. Komitmen Organisasi Memoderasi Hubungan Antara Efektivitas Laporan Keuangan Terhadap Kinerja Manajerial}

Berdasarkan hasil uji t pada table 5.10 diketahui bahwa partisipasi anggaran memiliki $\mathrm{t}$ hitung sebesar 1,091 t table sebesar 2,060. Dalam hal ini nilai t hitung $>\mathrm{t}$ table $(1,091>2.060)$ dengan sig 0,700 hasil tersebut dapat disimpulkan bahwa variabel efektivitas laporan keuangan berpengaruh positif dan tidak signifikan terhadap kinerja manajerial. 
Laporan Keuangan merupakan suatu informasi yang menggambarkan kondisi suastu perusahaan, dimana selanjutnya itu akan menjadi suatu informasi yang menggmbarkan tentang kinerja perusahaan (Pujiastuti et al., 2020).

Penelitian lain yang dilakukan oleh (Wiratno et al., 2017) penelitian ini mengatakan bahwa partisipasi anggaran berpengaruh positif signifikan terhadap kinerja manajerial. Adapun Penelitian yang lainnya (Madrasah et al., 2016) menghasilkan komitmen organisasi positif dan signifikan terhadap efektivitas implementasi rencana stratejik. (Carolina, 2021) mengatakan efektivitas proses bisnis dan komitmen organisasi secara bersama-sama terbukti berpengaruh terhadap kualitas sistem informasi akuntansi Pembahasan dimaksudkan untuk memaknai hasil penelitian sesuai dengan teori yang digunakan dan tidak sekadar menjelaskan temuan. Pembahasan harus diperkaya dengan merujuk hasil-hasil penelitian sebelumnya yang telah terbit dalam jurnal ilmiah.

\section{KESIMPULAN}

Berdasarkan hasil penelitian yang telah dilakukan melalui tahap pengumpulan data, pengolahan data, dan analisis data dapat ditarik kesimpulan sebagai berikut :

Secara parsial partisipasi anggaran berpengaruh dan signifikan terhadap kinerja manajerial. Berdasarkan hasil uji t bahwa partisipasi anggaran memiliki t hitung sebesar 2,532, $\mathrm{t}$ table sebesar 2,060. Dalam hal ini nilai t hitung $>\mathrm{t}$ table $(2,532>2,060)$ dengan sig 0,018. Sehingga penelitian ini diterima hipotesis satu (H1) yang telah diajukan.

Secara parsial efektifitas laporan keuangan tidak berpengaruh dan tidak signifikan terhadap kinerja manajerial. Berdasarkan hasil uji t diketahui bahwa efektifitas laporan keuangan memiliki t hitung sebesar $-0,137, \mathrm{t}$ table sebesar 2,060. Dalam hal ini nilai t hitung $>\mathrm{t}$ table ($0,137>2,060)$ dengan sig 0,892 . Sehingga penelitian ini menolak hipotesis dua (H2) yang telah diajukan.

Secara parsial gaya kepemimpinan memiliki efek moderasi partisipasi anggaran terhadap kinerja manajerial. Berdasarkan hasil uji t diketahui bahwa partisipasi anggaran memiliki t hitung sebesar 2,578, $\mathrm{t}$ table sebesar 2,060. Dalam hal ini nilai t hitung $>\mathrm{t}$ table $(2,578>2,060)$ dengan sig 0,017 sehingga penelitian ini diterima hipotesis tiga (H3) yang telah diajukan.

Secara parsial gaya kepemimpinan tidak mampu menjadi moderasi pengaruh efektifitas laporan keuangan terhadap kinerja manajerial. Berdasarkan hasil uji t diketahui bahwa efektifitas laporan keuangan memiliki t hitung sebesar 1,091 t table sebesar 2,060. Dalam hal ini nilai $t$ hitung $>\mathrm{t}$ table $(1,091>2.060)$ dengan sig 0,700 . Sehingga penelitian ini ditolak hipotesis keempat $(\mathrm{H} 4)$ yang telah diajukan.

\section{DAFTAR PUSTAKA}

Annisa, F., Sariningsih, E., \& Luthfi, M. (2020). Pengaruh Partisipasi Penyusunan Anggaran, Kejelasan Sasaran Anggaran, Profesionalisme Sumber Daya Manusia Dan Komitmen Organisasi Terhadap Kinerja Manajerial (Studi Kasus Pada Skpd Kabupaten Pesawaran). Jurnal Ilmiah Akuntansi Rahmaniyah, 3(2), 1. https://doi.org/10.51877/jiar.v3i2.149

Ariska, N. (2019). Pengaruh Efektifitas Sistem Informasi Akuntansi Dan Pengendalian Internal Terhadap Kinerja Manajerial ( Studi Kasus pada PT PJB UBJOM PLTMG ARUN ). $5,91-100$.

Carolina, Y. (2021). Pengaruh Efektivitas Proses Bisnis Dan Komitmen Organisasi Terhadap Kualitas Sistem Informasi Akuntansi ( Survei Pada Perusahaan Asuransi Umum Di Kota Bandung ). 3, 33-54.

Dewi, L. P. W., Sastri, I. I. D. A. M., \& Sanjaya, I. K. P. W. (2021). Pengaruh Partisipasi Anggaran, Akuntabilitas Publik dan Gaya Kepemimpinan Terhadap Kinerja Manajerial Pada Organisasi Perangkat Daerah Kabupaten Bangli. Jurnal Riset Akuntansi Warmadewa, 2(2), 75-81. 
Ermawati, N. (2017). Pengaruh Partisipasi Anggaran Terhadap Kinerja Manajerial Dengan Motivasi Kerja Sebagai Variabel Pemoderasi (Studi Kasus Skpd Kabupaten Pati). Jurnal Akuntansi Indonesia, 6(2), 141. https://doi.org/10.30659/jai.6.2.141-156

Ghozali, I. (2016). Desain Penelitian Kuantitatif \& Kualitatif untuk Akuntansi, Bisnis dan Ilmu Sosial Lainnya. Universitas Diponegoro.

Gunawan, A. C., \& Santioso, L. (2015). Pengaruh Partisipasi Anggaran Terhadap Kinerja Manajerial Melalui Komitmen Organisasi Dan Motivasi Sebgai Variabel Moderating. Jurnal Akuntansi, XIX(01), 144-159.

Iswahyudi, I., Pangayow, B. J. C., \& Wijaya, A. H. . (2020). Pengaruh Partisipasi Anggaran Terhadap Kinerja Manajerial Dengan Motivasi Kerja Sebagai Variabel Pemoderasi (Studi Kasus Pada Organisasi Perangkat Daerah (OPD) Di Kota Jayapura). Jurnal Akuntansi Dan Keuangan Daerah, 14(1). https://doi.org/10.52062/jakd.v14i1.1449

Madrasah, G., Negeri, A., \& Kabupaten, C. (2016). Pengaruh kepemimpinan partisipatif dan komitmen organisasi terhadap efektifitas implementasi rencana stratejik pada madrasah aliyah di kabupaten sukabumi jawa barat. 1, 114-129.

Ni Putu Medhayanti1 Ketut Alit Suardana (2015) Pengaruh Partisipasi Anggaran Terhadap Kinerja Manajerial dengan Self Efficacy,Desentralisasi,Dan Budaya Organisasi sebagai Variabel Pemoderasi, E-Jurnal Akuntansi Universitas Udayana.11.1 (2015): 155-170. ISSN: 2302-8556

Prof. Dr. Sugiyono. (2019). Metode Penelitian Kuantitatif Kualitatif R\&D. Alfabeta.

Pujiastuti, D., Sa'diyah, K., Lestari, S. I., Kabib, N., Taufiqi, M., \& Mustofa, L. (2020). Analisis Efektivitas Dan Efisiensi Laporan Keuangan Pemerintah Kecamatan Ungaran Kabupaten Semarang Tahun 2017-2018. 01(09), 102-108.

Saraswati, gita pramudya. (2015). Pengaruh partisipasi penyusunan anggaran terhadap kinerja manajerial dengan. Jurnal Akuntansi, 295-300.

Sari, D. N., Mintarti, S., \& Pattisahusiwa, S. (2018). Analisis efektivitas dan efisiensi $\begin{array}{llll}\text { pelaksanaan } \quad \text { anggaran } & \text { belanja. }\end{array}$ https://doi.org/10.29264/jkin.v15i1.4051

Wibawa, D. F., \& Suhardiyah, M. (2021). Pengaruh Partisipasi Penyusunan Anggaran dan Komitmen Organisasi Terhadap Kinerja Manajerial Pada PT. Daya Matahari Utama. Journal of Sustainability Business Research, 2(1), 4452. https://doi.org/10.36456/jsbr.v2i1.3386

Wiratno, A., Ningsih, W., \& Putri, N. K. (2017). Partisipasi Anggaran Terhadap Kinerja Manajerial Dengan Komitmen Organisasi, Motivasi Dan Struktur Desentralisasi Sebagai Variabel Pemoderasi. Jurnal Akuntansi, 20(1), 150. https://doi.org/10.24912/ja.v20i1.81

Yuniarti, E., \& Saty, F. M. (2019). Pengaruh Komitmen Organisasi Dan Gaya Kepemimpinan Terhadap Hubungan Antara Partisipasi Anggaran Dan Kinerja Manajerial ( Studi Empiris Pada Kantor Cabang Perbankan Di Propinsi Lampung ) The effect of organizational commitment and leadership style towards. Jurnal Ilmiah ESSAI, 2(1), $1-16$.

Yusuf, R. M., \& Syarif, D. (2017). KOMITMEN ORGANISASI Definisi, Dipengaruhi \& Mempengaruh. In Makassar: Penerbit Nas Media Pustaka (Vol. 11, Issue 1). 